\title{
PROSES PERUBAHAN MENDASAR KONSTITUSI INDONESIA PRA DAN PASCA AMANDEMEN
}

\author{
Sonia Ivana Barus \\ Fakultsa Hukum Universitas Indonesia \\ Email : niaivanabarus@gmail.com
}

\begin{abstract}
In the system of legal norms in the Republic of Indonesia, Pancasila is a very fundamental norm and is the highest legal norm and then the 1945 Constitution. As one of the basic norms of the Republic of Indonesia, several times there have been debates when a constitution in this case is a Constitution 1945 whether it can experience changes or cannot experience changes. This paper will discuss how the process and what are the fundamental changes experienced by the Indonesian constitution on amendments. The results of the analysis and explanation show that, the 1945 Constitution of the Republic of Indonesia (UUD 1945) in the Historical Process, has gone through four stages of change, namely: the 1945 Constitution. Meanwhile, in the process of constitutional changes after the return to the 1945 Constitution Indonesia has made at least four amendments. If you look at the process of changing the Constitution from its history, several times the political power is used to interpret the constitution. The author concludes that politics cannot be separated from the legal system. Likewise with the law, it cannot be released from the political system. Both of them synergize with each other so as to create a government system that is expected to become good governance and bring benefits to all people. However, the writer views that the law is often used as a political tool to smooth the desires of a handful of people.
\end{abstract}

\section{Keywords : Process; Amendment; Constitution; Indonesia}

\begin{abstract}
ABSTRAK
Di dalam sistem norma hukum di Negara Republik Indonesia, Pancasila merupakan norma yang sangat fundamental dan merupakan norma hukum tertinggi dan kemudian dibawahnya terdapat UUD 1945. Sebagai salah satu norma dasar Republik Indonesia, beberapa kali sempat terjadi perdebatan ketika suatu konstitusi yang dalam hal ini adalah UUD 1945 apakah dapat mengalami perubahan atau tidak dapat mengalami perbuahan. Tulisan ini akan membahas bagaimana proses dan apa-apa saja perubahan mendasar yang dialami oleh konstitusi Indonesia paca amandemen. Hasil analisis dan penjelasan diketahui bahwa, Undang-Undang Dasar Negara Republik Indonesia Tahun 1945 (UUD 1945) dalam Proses sejarah, telah melalui 4 tahapan perubahan yakni adalah: Undang-Undang Dasar 1945. Sementara itu, dalam proses perubahan konstitusi pasca kembalinya ke UUD 1945, Indonesia telah melakukan setidaknya empat kali amandemen. Jika melihat pada proses perubahan Konstitusi dari sejarahnya, beberapa kali kekuatan politik dipergunakan untuk mentafsirkan konstitusi. Penulis berkesimpulan bahwa politik tidak mungkin dapat dilepaskan dari sistem hukum. Begitu juga dengan hukum, tidak mungkin dapat dilepaskan dari sistem perpolitikan. Keduanya saling bersinergi satu sama lainnya sehingga menciptakan suatu sitstem pemerintahan yang diharapkan menajadi pemerintahan yang baik dan mendatangkan manfaat
\end{abstract}


bagi seluruh rakyat. Akan tetapi penulis berpandangan kerap kali hukum dijadikan alat berpolitik untuk memuluskan keinginan segelintir orang.

\section{Kata Kunci : Proses; Amandemen; Konstitusi; Indonesia}

Pendahuluan

Dalam bukunya, Prof. Satya Arinanto mengemukakan bahwa the expanded Committe elected Soekarno and Hatta as respectively president and vice residentof the Republic of Indonesia. It appointed a commission of sevento finalise the national constitution to finalise the national constitution, which had been drafted in the month before the Japanese capitulation. ${ }^{1}$ Hal ini membuktikan bahwa Indonesia sudah memiliki konstitusinya bahkan diawal-awal masa kemerdekaannya.

Konstitusi sendiri telah dikenal sejak lama bahkan sejak jaman Yunani Kuno. Hal ini dapat dibuktikan dengan adanya berbagai pemikiran dari filsuf-filsuf ternama Yunani Kuno seperti Plato. Plato pada saat itu bahkan diklaim menagut teori kontark sosial dimana teori kontrak sosial inilah yang disebut-sebut menjadi cikal-bakal lahirnya konstitusi pada masa sekarang. Meskipun penulisanya tidak sebaku pada masa sekarang, secara tidak langsung konstitusi telah muncul meskipun dalam bentuk yang sangat sederhana.

\footnotetext{
${ }^{1}$ Satya Arinanto, Constitutional Law and Democratization in indonesia (Jakarta: Publishing House Faculty of Law University of Indonesia, 2000), hal. 141
}

Faham ini teryata juga muncul dengan konteks yang lebih kompleks yang dikembangkan oleh Aristoteles. Aristoteles membedakan istilah politea dan nomoi. Politea diartikan sebagai konstitusi sedangkan nomoi diartikan sebagai undangundang biasa. Diantara kedua istilah tersebut terdapat perbedaan yaitu bahwa politea mengandung kekuasaan yang lebih tinggi daripada nomoi, karena politea mempunyai kekuasaan untuk membentuk sedangkan pada nomoi kekuasaan itu tidak ada, karena ia hanya merupakan materi yang harus dibentuk agar supaya tidak bercrai berai. ${ }^{2}$

Pemahaman terhadap konstitusi kemudian berkembang hingga abad pertengahan. Pada masa ini, konstitusi juga masih menjadi hal yang berbeda dengan konstitusi yang sekarang ini kita kenal. Di abad pertengahan pada jaman Romawi, perpindahan kekuasaan raja dilakukan secara mutlak, sehingga raja memiliki kekuasaan yang mutlak pula. Namun kemudian munculah kaum monarchomachen yakni kaum yang membenci adanya sistem kekuasaan raja yang mutlak. Untuk mencegah kekuasaan raja yang mutlak tersebut, maka golongan ini mengkhendaki

\footnotetext{
${ }^{2}$ Moh. Kusnardi dan Harmaily Ibrahim, Pengantar Hukum Tata Negara indonesia (Jakarta: Fakultas Hukum universitas Indonesia, 1983), hal. 62
} 
suatu perjanjian dengan raja. Golongan ini memgkhendaki agar raja dapat dipecat atau bahkan dibunuh jika melanggar perjanjian tersebut. Lambat-laun perjanjian antara rakyat dengan raja ini dituangkan dalam satu naskah yang disebut dengan Leges Fundamentalis. Dari sinilah mulai tampak bahwa perjanjian antara rakyat dan pemerintah yang menjadi awal lahirnya konstitusi yang kemudian di tuliskan dalam bentuk naskah.

Konstitusi adalah hukum dasar yang dijadikan pegangan dalam penyelenggaraan suatu negara. Konstitusi dapat berupa hukum dasar tertulis yang lazim disebut UndangUndang Dasar, dan dapat pula tidak tertulis. Tidak semua negara memiliki konstitusi tertulis atau Undang-Undang Dasar. Kerajaan Inggris biasa disebut sebagai negara konstitusional, tetapi tidak memiliki satu naskah Undang-Undang Dasar sebagai konstitusi tertulis, disamping karena adanya negara yang dikenal sebagai negara konstitusional, tetapi tidak memiliki konstitusi tertulis, nilai dan norma yang hidup dalam praktik penyelenggaraan negara juga diakui sebagai hukum dasar, dan tercakup pula dalam pengertian konstitusi dalam arti yang luas. Oleh karena itu Undang-Undang Dasar sebagai konstitusi tertulis beserta nilai-nilai dan norma hukum dasar tidak tertulis yang hidup sebagai konvensi ketatanegaraan dalam praktik penyelenggaraan negara sehari-hari, termasuk kedalam pengertian konstitusi atau hukum dasar (droit constitusionel) suatu negara. $^{3}$

Di dalam sistem norma hukum di Negara Republik Inndonesia, Pancasila merupakan norma yang sangat fundamental dan merupakan norma hukum tertinggi dan kemudian dibawahnya terdapat UUD 1945. Seperti yang telah disebutkan diatas, bahwa konstitusi Indonesia adalah UUD 1945 (Undang-Undang Dasar 1945). Sebagai aturan yang mendasar, UUD 1945 harus mampu merefleksikan norma tertinggi di Indonesia yakni adalah pancasila. UndangUndang Dasar menciptakan pokok-pokok pikiran yang terkandung dalam pembukaan di dalam pasal-pasalnya. Pokok-pokok pikiran tersebut meliputi suasana kebatinan dari Undang-Undang Dasar Negara Republik Indonesia. Pokok-pokok pikiran ini mewujudkan cita-cita hukum (Rechtsidee) yang menguasai hukum dasar negara, baik hukum yang tertulis (Undang-Undang Dasar) maupun hukum yang tidak tertulis. UndangUndang Dasar menciptakan pokok-pokok pikiran ini di dalam pasal-pasalnya. ${ }^{4}$

Undang-Undang Dasar Indonesia sendiri ternyata menempatkan Pancasila di dalam pembukaannya. Berdasarkan hal tersebut, dapatlah diketahui bahwa

\footnotetext{
${ }^{3}$ Jimly Asshiddiqie, Konstitusi dan

Konstitusionalisme Indonesia(Jakarta: Sinar Grafika, 2014), hal. 29

${ }^{4}$ Maria Farida, Ilmu Perundang-Undangan: Jenis, Fungsi dan Materi Muatan (Yogyakarta: Kanisius, 2007), hal. 58
} 
kedudukan dari pembukaan UUD 1945 adalah lebih utama daripada batang tubuh (pasal-pasal) yang terdapat di dalam UUD 1945 karena pembukaan UUD 1945 sendiri mengandung pokok-pokok utama yakni adalah pancasila. Sebagai salah norma dasar Republik Indonesia, beberapa kali sempat terjadi perdebatan ketika suatu konstitusi yang dalam hal ini adalah UUD 1945 apakah dapat mengalami perubahan atau tidak dapat mengalami perbuahan. Banyak terjadi perdebatan panjang mengenai hal ini, ada yang berpandangan bahwa UUD 1945 tidak dapat diubah dan adapula yang berpandangan bahwa UUD 1945 dapat diubah. Sebenarnya, bahwa konstitusi memang dibuat sulit untuk diubah karena dengan demikian menjadi berbeda dengan norma hukum biasa. $^{5}$ Namun, sebenarnya mau tidak mau, Indonesia sendiri telah mengalami beberapa kali perubahan konstitusi dari segi sejarah maupun segi prosesnya. Indonesia sudah melakukan perubahan konstitusi baik secara keseluruhan maupun hanya sebatas memperbaiki sebagian ketentuan saja. Pada perjalanannya UUD 1945 yang merupakan produk dari Panitia Persiapan Kemerdekaan Indonesia (PPKI) yang disahkan dan ditetapkan pada hari sabtu 18 Agustus $1945 .{ }^{6}$ Sebagai konstitusi tertulis, UUD 1945

\footnotetext{
${ }^{5}$ Hans Kelsen, General Theory of Law dalam Politik Hukum 2 oleh Prof. Satya Arinanto (Jakarta: Program Pasca Sarjana Fakultas Hukum Universitas Indonesia, 2004), hal. 7

${ }^{6}$ Dahlan Thaib, et. al, Teori dan Hukum Konstitusi (jakarta: Rajawali Press, 2004), hal. 83
}

dituangkan dalam sebuah dokumen formal. Dimana perancangan awalnya dilakukan oleh Badan Penyelidik Usaha-Usaha Persiapan Kemerdekaan Indonesia (BPUPKI), dengan dua masa sidang yaitu tanggal 29 Mei-1 Juni 1945 dan tanggal 10-17 Juli 1945 . $^{7}$

Ini membuktikan bahwa sebenarnya UUD 1945 yang dalam hal ini merupakan konstitusi Indonesia dapat berubah. Akan tetapi yang perlu digarisbawahi adalah, perubahan tersebut hanyalah pada batang tubuh UUD 1945 saja, bukan pada bagian pembukaannya. Hal ini terjadi karena, seperti yang telah di jelaskan diatas sebelumnya, Pembukaan UUD 1945 mengandung nilainilai yang ada di dalam Pancasila yang merupakan norma fundamental Negara (Staatsfundamentalnorm).

Perlu diketahui juga, hampir semua negara yang mengalami transisi ke demokrasi menjadikan reformasi konstitusi sebagai bagian takterpisahkan dari pembaharuan politik mereka. Demikian pentingnya reformasi konstitusi itu, sehingga kehadirannya dipandang sebagai suatu keharusan. Tidak jelas benar kapan suatu negara yang tengah mengalami transisi mulai melaksanakan reformasi konstitusi. Sejauh yang dapat dibaca dari berbagai literatur mengenai transisi ke demokrasi, pengalaman masing-masing negara dalam hal ini relatif

\footnotetext{
${ }^{7}$ Saefroedin Bahar, et. al, Risalah Sidang BPUPKIPPKI (Jakarta: Sekretariat Negara Republik Indonesia, 1992), hal. 137
} 
berbeda. Filipina misalnya mulai melakukan reformasi konstitusi dengan membentuk komisi konstitusi, dimana tugas utamanya adalah menuliskan kembali undang-undang dasar negeri itu tak lama setelah Presiden Marcos dijatuhkan, dan setelah pemerintahan baru Cory Aquino terbentuk. ${ }^{8}$ Sama dengan produk-produk hukum lainnya, idealnya, suatu konstitusi memang dibuat untuk memenuhi kebutuhan demi terciptanya kekuasaan negara dengan cabang-cabang kekuasaannya. Tetapi juga tidak dapat dipungkiri bahwa kosntitusi adalh produk dari zamannya, bukan merupakan hal yang salah jika isinya adalah untuk mengakomodasi kepentingan-kepentingan pada saat zamannya tersebut. Oleh karena itu, tanpa adanya perubahan memaksa yang bersifat ektrimpun reformasi konstitusi sebenarnya memang harus dilakukan perubahan demi mengikuti perkembangan zaman yang ada.

Pada dasarnya kemungkinan untuk mengadakan perubahan atau penyesuaian itu memang sudah dilihat oleh para penyusun UUD 1945 itu sendiri, dengan merumuskan dan melalui pasal 37 UUD 1945 tentang perubahan Undang-Undang Dasar. Dan apabila MPR bermaksud akan mengubah UUD melalui pasal 37 UUD 1945 , sebelumnya hal itu harus ditanyakan lebih

\footnotetext{
${ }^{8}$ Bachtiar Effendi, Repolitisasi Islam: Pernahkah Islam Berhenti Berpolitik? (Jakarta: Mizan, 2000), hal. 339
}

dahulu kepada seluruh Rakyat Indonesia melalui suatu referendum.(Tap No.1/ MPR/1983 pasal 105-109 jo. Tap no.IV/MPR/1983 tentang referendum). ${ }^{9}$ Dari pemaparan diatas, maka menarik untuk dibahas bagaimana proses apa-apa saja perubahan mendasar yang dialami oleh konstitusi Indonesia paca amandemen

\section{Pembahasan}

Ada beberapa teori yang perlu diketahu sebelum masuk kedalam pembahasan proses perubahan Undang-Undang Dasar Negara Republik Indonesia yakni adalah: Dalam bukunya Politica, Aristoteles mengatakan: ${ }^{10}$

" Konstitusi merupakan penyusunan jabatan dalam suatu negara dan menentukan apa yang dimaksud dengan badan pemerintahan, dan apa akhir dari setiap masyarakat, konstitusi merupakan aturan-aturan dan penguasa harus mengatur negara menurut aturan-aturan tersebut. "

Konstitusi sendiri pada prakteknya kerap kali disamakan dengan istilah-istilah seperti Undang-Undang Dasar, aturan dasar atau hukum dasar. Ternyata, konstitusi dalam bahasa Indonesia berasal dari kata constitutio (bahasa Inggris), constitutie (bahasa Belanda), constitutionel (bahasa Perancis), verfassung (bahasa Jerman), constitutio

\footnotetext{
${ }^{9}$ Website Mahkamah Konstitusi (https://mkri.id/index.php?page=web.Berita\&id=1177 6), "Sejarah dan Perkembangan Konstitusi di Indonesia", Kamis 13 Agustus 2015, diakses pada tanggal 20 November 2016 Pukul 22:14

10 Azhary, Negara Hukum Indonesia Analisis Yuridis Normatif Tentang Unsur-Unsurnya (Jakarta: Universitas Indonesia Press, 1995), hal 21
} 
(bahasa Latin), fundamental laws (Amerika Serikat). ${ }^{11}$ Perkataan "Konstitusi" berarti "pembentukan" berasal dari kata kerja constituer (bahasa Perancis) yang berarti "membentuk". 12 Sedangkan, istilah UUD adalah terjemahan dari bahasa Belanda grondwet. Dalam kepustakaan Belanda, selain grondwet juga digunakan istilah constitutie. Kedua istilah tersebut mempunyai pengertian yang sama.

Dalam perkembangannya, konstitusi memiliki dua pengertian yakni adalah konstitusi dalam arti sempit dan konstitusi dalam arti luas. Konstitusi dalam arti sempit ialah tidak menggambarkan seluruh kumpulan peraturan, baik yang tertulis dan tidak tertulis (legal and non legal) maupun yang dituangkan dalam suatu dokumen tertentu seperti berlaku di Amerika Serikat. ${ }^{13}$ Konstitusi sebagai kaidah yang tertuang dalam suatu dokumen khusus dikenal dengan sebutan Undang-Undang Dasar. Sekedar catatan perlu juga diutarakan bahwa ada yang memandang UUD itu bukan kaidah hukum melainkan kumpulan pernyataan (manifesto), pernyataan tentang keyakinan, pernyataan

11 Rukmana Amanwinata, Pengaturan dan Batas Implementasi Kemerdekaan Berserikat dan Berkumpul Dalam pasal 28 UUD 1945 dalam Ellydar Chaidir, Hukum dan Teori Konstitusi (Yogyakarta: Total Media, 2007), hal 20-21

${ }^{12}$ Wirjono Prodjokoro, Azas-azas Hukum Tata Negara di Indonesia (Jakarta: Dian Rakyat, 1977), hal. 21

13 Sri Soemantri, Pengantar Perbandingan Antar Hukum Tata Negara (Jakarta: Rajawali, 1981), hal. 22 cita-cita. ${ }^{14}$ Sedangkan Eric Barendt dalam bukunya Introduction to Constitutional Law menyatakan Konstitusi negara adalah dokumen tertulis atau teks yang mana secara garis besar mengatur kekuasaan legislatif, eksekutif, dan yudikatif, serta lembaga negara lainnya. ${ }^{15}$

Selanjutnya Herman Heller, membagi pengertian konstitusi menjadi tiga yakni adalah: ${ }^{16}$

1. Die Politische verfassung als gesellschaftlich wirklichkeit. Konstitusi adalah mencerminkan kehidupan politik di dalam masyarakat sebagai suatu kenyataan. Jadi mengandung pengertian politis dan sosiologis.

2. Die Verselbstandigte rechtsverfassung.Konstitusi merupakan satu kesatuan kaidah yang hidup dalam masyarakat. Jadi mengandung pengertian yuridis.

3. Die geshereiben verfassung. Konstitusi yang ditulis dalam suatu naskah sebagai undang-undang yang tertinggi yang berlaku dalam suatu negara.

\footnotetext{
${ }^{14}$ Bagir Manan, Pertumbuhan dan Perkembangan Konstitusi Suatu Negara (Bandung: Mandar Maju, 1994), hal. 32

${ }^{15}$ Eric Barendt, Introduction to Constitutional Law (Inggris: Oxford University Press, 1998), hal. 33

${ }^{16}$ Mohammad Kusnardi dan Harmaily Ibrahim, Op., Cit., hal. 65-66
} 
Berdasarkan pendapat Heller diatas, konstitusi fleksibel adalah (a) elastis, (b) dapatlah diketahui bahwa Undang-Undang diumumkan dan diubah dengan cara sama Dasar adalah merupakan salah satu bagian dari pengertian konstitusi. Dengan demkian, sesungguhnya konstitusi juga meliputi halhal yang berhubungan dengan konstitusi tidak tertulis yang merupakan norma-norma di tengah-tengah masyarakat yang dipergunakan dalam kehidupan kenegaraan.

Dalam penulisan ini, wajarlah jika penulis mengasumsikan bahwa yang dimaksud dengan konstitusi Indonesia adalah Undang-Undang Dasar Negara Republik Indonesia. Hal ini sejalan dengan apa yang telah disampaikan diatas, bahwa UndangUndang Dasar dalam hal ini adalah konstitusi tertulis dan merupakan salah satu makna dari konstitusi. Selain itu, melihat pada kebiasaan kenegaraan Indonesia, Konstitusi memang kerap kali dipersamakan dengan UndangUndang Dasar. Kita dapat mengambil contoh yakni nama lembaga negara di Indonesia "Mahkamah Konstitusi" yang seyogyanya adalah mahkamah yang memiliki tugas untuk melakukan judicial review materi muatan Undang-Undang terhadap Undang-Undang Dasar.

Berkaitan dengan hal diatas, ternyata konstitusi memiliki sifat-sifat yakni ada konstitusi yang bersifat flexible (luwes) dan ada yang bersifat rigid (kaku). ${ }^{17}$ Bryce mengemukakan ciri-ciri khusus dari

\footnotetext{
${ }^{17}$ Ibid.,, hal. 74
} seperti undang-undang. Sedangkan ciri-ciri konstitusi yang rigidadalah (a) mempunyai kedudukan dan derajat yang lebih tinggi dari peraturan perundang-undang yang lain, (b) hanya dapat diubah dengan cara yang khusus atau istimewa atau dengan persyaratan yang berat. $^{18}$

Adapun cara yang digunakan untuk mengubah Undang-Undang Dasar atau Konstitusi, memurut K.C. Wheare ada empat, yakni adalah: ${ }^{19}$

1. Beberapa kekuatan yang bersifat primer (Some Primary Forces);

2. Perubahan yang diatur dalam konstitusi (Formal Amandement);

3. Penafsiran secara hukum (Judicial Intrepertation);

4. Kebiasaan yang terdapat didalam bidang ketatanegaraan (Usage and Convention);

Sedangkan menurut C.F. Strong prosedur perubahan konstitusi dilakuakan dengan empat cara yakni adalah $:^{20}$

1. Perubahan Konstitusi yang dilakukan dengan batasan-batasan tertentu;

2. Perubahan Konstitusi yang dilakukan oleh rakyat melalui referendum;

\footnotetext{
18 Dahlan Thaib, Jazim Hamidi dan Ni'matul Huda, Teori dan Hukum Konstitusi (Jakarta: Raja Grafindo Persada, 2003), hal. 29

${ }^{19}$ Sri Soematri, Prosedur dan Sistem Perubahan Konstitusi (Bandung: Alumni, 2006), hal. 2018

${ }^{20}$ Dahlan Thaib, Op., Cit., hal. 51
} 
3. Perubahan Konstitusi yang dilakukan oleh negara-negara bagian;

4. Perubahan Konstitusi yang dilakukan oleh suatu konvensi atau dilakukan oleh lembaga negara khusus yang dibentuk hanya untuk keperluan perubahan;

Di Indonesia sendiri telah terjadi beberapa fase proes perubahan UndangUndang dasar. Yakni dapat ditinjau dari segi sejarah perubahan konstitusi di Indonesia dan juga dapat ditinjau dari segi perubahan konstitusi di Indonesia melalui amandemen. Yang menarik adalah semenjak perubahan konstitusi Indonesia (UUD 1945), tidak pernah sekalipun ada wacana untuk merubah Pembukaan Undang-Undang Dasar 1945. Alasan paling pragamatis mengapa hal ini terjadi adalah karena di dalam Pembukaan Undang-Undang Dasar 1945 terkandung nilai-nilai Pancasila, dimana Pancasila adalah sumber dari segara aturan di Indonesia. Akan tetapi beberapa menganggap bahwa dapat dirubah tidaknya Pembukaan UUD 1945 adalah masalah politik, kecuali ditentukan dalam UUD bahwa Pembukaan tidak boleh dirubah. Sedangkan Tap MPR yang menentukan "Pembukaan UUD 1945 tidak dapat diubah oleh siapapun, termasuk MPR hasil pemilihan umum", yakni peraturan dengan level lebih rendah yang mengatur materi peraturan derajat lebih tinggi. ${ }^{21}$

Menurutut penulis, perubahan terhadap tubuh Undang-Undang Dasar 1945, yang kemudian menyandang nama resmi UndangUndang Dasar Negara Republik Indonesia Tahun 1945 pasca dilakukannya amandemen setelah reformasi, adalah sesuatu hal yang wajar. Hal ini ini disebabkan oleh karena hukum tumbuh dan berkembang mengikuti deret hitung sementara masyarakat berkembang dan tumbuh dengan mengikuti deret ukur. Akan menjadi sangat tidak arif jika kita memaksakan agar Undang-Undang Dasar tetap menajdi sesuatu hal yang "dikeramatkan" seperti masa Ode Baru. Masalah yang kemudian menjadi perdebatan adalah ketika dimana Undang-Undang Dasar seharusnya tidak sering diubah-ubah, sebenarnya bukanlah suatu kesepakatan yang harus diamini. Memang benar, UndangUndang Dasar sebaiknya memang tidak seharusnya sering-sering berubah, akan tetapi, jika perubahan dalam masyarakat sendiri juga cepat berubah, diharapkan Undang-Undang Dasar juga dapat menyesuaikannya. Masalah sering atau tidaknya Undang-Undang Dasar itu berubah adalah bagaimana drafter kemudian mampu membaca situasi masa depan.

\footnotetext{
${ }^{21}$ Miftakhul Huda, "Pengujian UU dan Perubahan Konstitusi: Mengenal Lebih Dekat Gagasan Sri Soemantri”, Jurnal Konstitusi, 6:4 (Jakarta: November 2009), hal. 183
} 
Ada beberapa alasan mengapa UUD 1945 perlu disempurnakan dalam rangka reformasi hukum pasca orde baru, yaitu: ${ }^{22}$

a. Alasan historis, sejak semula dalam sejarahnya UUD 1945, memang didesain oleh para pendiri negara kita (BPUPKI, PPKI) sebagai UUD yang bersifat sementara, karena dibuat dan ditetapkan dalam suasana ketergesagesaan;

b. Alasan filosofis, dalam UUD 1945 telah terdapat pencampuradukan berbagai gagasan yang saling bertentangan, seperti faham kedaulatan rakyat dengan faham integralistik antara negara hukum dengan faham negara kekuasaan;

c. Alasan teoritis, dari sudut pandang teori konstitusi (konstitusionalisme), keberadaan konstitusi bagi suatu negara pada hakekatnya adalah untuk membatasi kekuasaan negara agar tidak bertindak sewenang-wenang, tetapi justru UUD 1945 kurang menonjolkan pembatasan kekuasaan tersebut, melainkan menonjolkan pengintegrasian.

d. Alasan yuridis sebagaimana lazimnya setiap kostitusi UUD 1945 juga mencantumkan klausula seperti dalam Pasal 37.

\footnotetext{
${ }^{22}$ Mukthie Fadjar, Reformasi Konstitusi dalam Masa Transisi Paradigmatik (Malang: In-Trans, 2003), hal. 39
}

e. Alasan praktis politis, bahwa secara sadar atau tidak, secara langsung atau tidak langsung, dalam praktek UUD 1945 sudah sering mengalami perubahan dan atau penambahan yang menyimpang dari teks aslinya dari masa 1945-1949, maupun 1959-1998.

\section{PROSES PERUBAHAN KONSTITUSI}

DALAM SEJARAH INDONESIA

a. UNDANG-UNDANG DASAR 1945 (UUD 1945)

Undang-Undang Dasar 1945 sebagai kontitusi tertulis merupakan konstitusi yang dituangkan dalam dokumen formal. Menurut sejarahnya, Undang-Undang Dasar 1945 dirancang oleh Badan Penyelidik UsahaUsaha Persiapan Kemedekaan pada tanggal 29 Mei 1945 sampai dengan tanggal 16 Agustus 1945, atau hanya dalam waktu 49 (empat puluh sembilan) hari kerja. Karena disusun dalam waktu yang singkat dan dalam suasana yang kurang memungkinkan, oleh penyusunnya UUD 1945 dikatakan sebagai UUD kilat. Ini jelas sekali tergambar dalam pidato Soekarno yang menjelaskan bahwa:

"UUD yang dibuat pada saat ini masih bersifat sementara dan apabila keadaan negara sudah dalam suasana yang lebih tentram maka akan dikumpulkan kembali MPR yang dapat membuat 
UUD yang lebih lengkap dan lebih sempurna". 23

Undang-Undang Dasar Republik Indonesia yang pertama ini adalah UUD 1945 yang disahkan pada tanggal 18 Agustus 1945, berlaku secara nasional sampai dengan tanggal 27 Desember 1949. Naskah Undang Undang Dasar Pertama tersebut disahkan oleh Panitia Persiapan Kemerdekaan Indonesia (PPKI). Penyusunan naskah Rancangan Undang-Undang Dasar 1945 dimulai dari pembentukan BPUPKI yang dilantik pada tanggal 28 Mei 1945. BPUPKI mengadakan sidang-sidang yang dapat dikelompokkan menjadi dua masa persidangan; Sidang pertama mulai dari tanggal 29 Mei 1945-1 Juni 1945 dan masa persidangan kedua tanggal 10 Juli-17 Juli 1945. Dari persidangan-persidangan BPUPKI tersebut berhasil disusun naskah komplit Rancangan Undang-Undang Dasar meliputi pernyataan Indonesia merdeka, Pembukaan Undang-Undang Dasar, dan Undang-Undang Dasar teridiri atas pasalpasal. $^{24}$

Dengan selesainya tugas BPUPKI, pemerintah Jepang membentuk Panitia Persiapan Kemerdekaan Indonesia (PPKI) yang bertugas untuk mempersiapkan segala

\footnotetext{
${ }^{23}$ Muhammad Yamin, Naskah Persiapan UndangUndang Dasar 1945(Jakarta: Siguntang, 1971), hal. 410

${ }^{24}$ Noor MS Bakry, Pancasila Yuridis Kenaegaraan (Yogyakarta: Liberty, 1994), hal. 23
}

sesuatu yang berhubungan dengan kemerdekaan Indonesia. Pada sidang tanggal 18 Agustus PPKI berhasil mengesahkan naskah Undang-Undang Dasar 1945 dari naskah Rancangan Undang-Undang Dasar hasil kerja BPUPKI tentunya dengan beberapa perubahan di sana sini. Terutama tentang dasar negara: Ketuhanan dengan kewajiban menjalankan syari'at Islam bagi pemeluk-pemeluknya sebagai mana termuat dalam Piagam Jakarta diubah menjadi Ketuhanan Yang Maha Esa. UUD 1945 berlaku dari 18 Agustus 1945 sampai 27 Desember 1949. Dalam perjalannya ternyata ada beberapa penyimpangan praktik kenegaraan yang sebenarnya sudah diatur dalam UUD 1945, misalnya para menteri tidak bertanggungjawab kepada presiden, tetapi kepada badan legislatif dan masih banyak lagi contoh yang lain. ${ }^{25}$

\section{b. KONSTITUSI RIS (REPUBLIK}

\section{INDONESIA SERIKAT)}

Indonesia yang pada saat itu baru saja merasakan kemerdekaan, Belanda ingin kembali berkuasa di Indonesia melalui Agresi Militer-I pada tahun 1947 dan Agresi Militer-II padda tahun 1948, namun agresi tersebut gagal. Setelah itu, pada tahun 1949 dilakukan KMB (Konfrensi Meja Bundar) di 
Den Haag, Belanda yang salah satu hasilnya adalah untuk mendirikan Republik Indonesia Serikat (RIS) dan disepakati serta mulai berlaku pada tanggal 27 desember 1949 .

Dengan disepakati dan berlakunya perjanjian ini, maka Negara Indonesia tetap ada, namun hanya merupakan salah satu dari negara bagian dari negara RIS. Dengan demikian, Undang-Undang Dasar 1945 yang hanya berlaku untuk negara Indonesia saja bukan negara RIS. Namun konstitusi ini tidak berlangusng lama tentunya, karena tidak sesuai dengan jiwa proklamasi Indonesia.

Pada tanggal 19 Mei 1950 disusunlah Piagam Persetujuan antara Pemerintah RIS yang sekaligus mewakili Negara bagian Indonesia Timur menyatakan menyetujui membentuk negara kesatuan. Dan tindak lanjut dari Piagam Persetujuan tersebut terbentuklah Negara Kesatuan dengan berdasar Undang-Undang Dasar Sementara 1950 tanggal 17 Agustus $1950 .^{26}$

\section{c. UNDANG-UNDANG DASAR} SEMENTARA (UUDS 1950)

Undang-Undang Dasar Sementara (UUDS 1950) ini menggantikan UUD RIS. UUDS ini dengan tegas menyatakan kedaulatan rakyat dan perlindungan Hak Asasi yang lebih merinci. Seperti yang

\footnotetext{
${ }^{26}$ Ibid., hal. 34
}

dikatakan oleh Adnan Buyung Nasution dalam bukunya: ${ }^{27}$

\section{"The 1950 Provisional Constitution replaced the 1949 Federal Constitution. This Constitution was more democratic than the previous constitutions. It firmly asserted the people's sovereignty and provided detailed protection for human rights, such as adopting the United Nations Declaration on Human Rights and incorporated the right to hold demonstrations and strikes".}

Dibawah UUDS 1950, pemilihan umum berhasil dilakukan yakni pada tahun 1955 untuk memilih anggota Dewakyat (DPR) dan memilih anggota Dewan Konstitusante. Dewan konstituante adalah dewan yang dibentuk untuk merumuskan UUD yang baru yang diharapkan akan dapat menggantikan UUDS 1950. Namun ternyata dewan yang dibentuk melalui pemilihan umum ini belum mampu mewujudkan UUD baru karena sulitnya mencapai kesepakatan diantara para anggota dewan. Untuk itu Presiden Soekarno mencari jalan keluarnya dengan mengeluarkan Dekrit Presiden 5 Juli 1959, yang berisikan: Menetapkan pembubaran Konstituante; Menetapkan UUD 1945 berlaku lagi terhitung mulai tanggal penetapan Dekrit, dan tidak berlakunya lagi UUDS 1950; dan Menetapkan dalam waktu sesingkat-singkatnya pembentukan MPRS dan DPAS.

\footnotetext{
${ }^{27}$ Adnan Buyung Nasution, The Aspiration for Constitutional Government in Indonesia: A Socio Legal Study of the Indonesian Konstituante, 19561959 (Jakarta: Pustaka Sinar Harapan, 1992), hal. 27
} 
Dekrit ini mendapat dukungan sebagian besar rakyat Indonesia. Yang lebih penting lagi melalui Dekrit ini terjadi perubahan ketatanegaraan Indonesia, naskah UndangUndang Dasar 1945 menjadi berlaku kembali sebagai hukum tetinggi dalam Negara Kesatuan Republik Indonesia. ${ }^{28}$

\section{d. KEMBALI KE UUD 1945}

Ciri-ciri periode ini ialah dominasi yang sangat kuat dari presiden, terbatasnya peranan partai politik, berkembangnya pengaruh komunis, dan meluasnya peranan ABRI sebagai unsur sosial politik. Ketetapan MPRS No. III/MPRS/1963 yang mengangkat Soekarno sebagai presiden seumur hidup telah membatalkan pembatasan waktu lima tahun. Tahun 1960 Presiden Soekarno membubarkan Dewan Perwakilan Rakyat hasil pemilihan umum, padahal dalam penjelasan Undang-Undang Dasar 1945 secara eksplisit ditentukan bahwa presiden tidak mempunyai wewenang untuk berbuat demikian.

Kuatnya posisi presiden juga merambah dalam bidang-bidang lain di luar bidang eksekutif. Berdasarkan UndangUndang No. 19 tahun 1964 Presiden diberi wewenang untuk campur tangan di bidang yudikatif. Dan masih Banyak lagi

\footnotetext{
${ }^{28}$ Kus Edy Sartono, "Kajian Konstitusi Indonesia dari Awal Kemerdekaan Hingga Era Reformasi”, Jurnal Humanika, 9:1 (Yogyakarta: Maret 2009), hal. 100
}

penyimpangan-penyimapangan terhadap Undang-Undang Dasar 1945 sebagaimana dibeberkan oleh Miriam Budiardjo ${ }^{29}$. Puncaknya pecahnya peristiwa G 30 S/PKI telah mengakhiri periode demokrasi terpimpin dan membuka jalan untuk di mulainya masa demokrasi Pancasila.

Hingga akhirnya, pemerintahan Soekarno digantikan oleh Pemerintahan Soeharto yang ditandai dengan lahirnya era Orde Baru. Pada masa ini, Presiden Soeharto membuat intrepertasi sistem pemerintahan yang menyimpang dari "itensi" para penyusun UUD 1945. Presiden Soeharto membuat intepretasi bahwa sistem pemerintahan kita adalah "Execitive Heavy". Inteprertasi itu hanya di dasarkan pada kunci pokok ke-IV yang berbunyi: "Dalam menyelenggarakan Pemerintahan Negara, kekuasaan dan tanggung jawab adalah ditangan Presiden (concerntation of power and responsibility upon the President). ${ }^{30}$ Padahal, bila dilihat lagi kepada kinci pokok ke-II, IV dan penjelasan Pasal 23 UUD, maka akan dapat disimpulkan bahwa legislatif lebih kuat.

Penafsiran pasal-pasal UUD 1945 yang dimanipulasi demi kepentingan kekuasaan. Bahkan Undang-Undang Dasar 1945 yang

\footnotetext{
${ }^{29}$ Miriam Budiardjo, Dasar-Dasal Ilmu Politik (Jakarta: Garmedia, 2006), hal. 71

${ }^{30}$ RM. A.B. Kusuma, Sistem Pemerintahan "Pendiri Negara” Versus Sistem Presidensiel "Orde Reformasi" (Jakarta: Fakultas Hukum Universitas Indonesia, 2011), hal. 50
} 
singkat dan fleksibel mudah disalahtafsirkan dan dipergunakan untuk menguntungkan penguasa, dibuat seolah-olah tidak untuk diamandemen bukan demi rakyat, tetapi demi kekuasaan.

Pengalaman pada masa Orde Lama dengan Undang-Undang Dasar 1945 posisi presiden yang sangat kuat, terulang lagi pada masa Orde Baru. Posisi legislatif berada di bawah presiden. Hak asasi rakyat juga dibatasi. Kekuasaan tanpa kontrol akibatnya pemerintahan Orde Baru cenderung melakukan penyimpangan di berbagai aspek kehidupan. Korupsi Kolusi dan Nepotisme (KKN) terjadi di semua lini tubuh pemerintahan. Terjadi ketidakmerataan pembangunan, kesenjangan antara yang kaya dan miskin, utang semakin banyak, akhirnya menumpuk menjadi krisis moneter. Dipelopori oleh mahasiswa, rakyat menuntut reformasi di segala bidang. Akhirnya Rezim Orde Baru tumbang dengan mundurnya Soeharto tanggal 21 Mei 1998.

Setelah Orde Baru tumbang, lahirlah era reformasi yang pada saat itu dipimpin oleh B.J. Habibie. Berbagai tuntutan kemudian disuarakan oleh elemen-elemen masyarakat yang akhirnya membentuk Kabinet Reformasi Pembangunan. Namun Kabinet ini tidak berumur panjang. Sekitar 13 (tiga belas) bulan kemudian diselenggarakanlah pemilihan umum 1999 untuk memilih anggota DPR. Satu setengah tahun berkuasa, Presiden B.J. Habibie pun harus meletakkan jabatannya setelah pidato pertanggungjawabannya ditolak oleh MPR dalam sidang umumnya pada tanggal 19 Oktober $1999 .^{31}$

Kepemimpinan B.J. Habibie lalu digantikan oleh Abdurrahman Wahid sebagai Presiden Republik Indonesia. Seperti yang dikatakan oleh Harold Crouch:

'In contrast to Indonesia's first two presidents who were always elected unanlimitedly and third who as viceprecident, acceded to the presidency on the resignation of his predecessor, President Abdurrahman won office in a competitive and constitutional process...". 32

Namun, kepemimpinan Abdurrahman tidak berlangsung lama hanya sekitar 20 bulan setelah diguncang oleh skandal bulog dan kemudian digantikan oleh Presiden Megawati Soekarno Puteri yang sebelumnya menjabat sebagai Wakil Presiden.

\section{PROSES PERUBAHAN KONSTITUSI} DALAM MASA AMANDEMEN

\section{a. AMANDEMEN PERTAMA}

Kelemahan dan ketidaksempurnaan konstitus yang merupakan hasil karya manusia adalah

\footnotetext{
${ }^{31}$ Satya Arinanto, "Politik Pembangunan Hukum Nasional dalam Era Pasca Reformasi", Makalah diberikan pada perkuliahan Politik Hukum Program Pasca Sarjana 2016

${ }^{32}$ Harold Crouch, Indonesia Democratization and Threat of Disintegration dalam Politik Hukum 2 oleh Prof Satya

Arinanto (Jakarta: Program Pasca Sarjana, Fakultas Hukum, Universitas Indonesia, 2004), hal. 356
} 
sesuatu hal yang pasti. ${ }^{33}$ Bahakan hal itu telah diungkapkan oleh Soekarno dalam pidatonya di dalam rapat PPKI, seperti yang telah dijelaskan dalam bab sebelumnya. Perlunya perubahan terhadap UUD 1945 sebenarnya adalah gagasan yang telah diungkapkan semenjak jaman Orde Baru. UUD dipandang terlalu summier, terlalu banyak masalah-masalah yang diserahkan kepada pembuat peraturan yang lebih rendah. Serta tidak menjamin secara tegas tentang hak-hak asasi manusia (HAM). ${ }^{34}$ Untuk itu, wajarlah jika terjadi perubahanperubahan dalam konstitusi. Amandemen konstitusi dimaksudkan agar negara Indonesia benar-benar merupakan pemerintahan yang konstitusional (constitutional government). Pemerintah konstitusional tidak hanya pemerintahan itu berdasarkan pada sebuah konstitusi, tetapi konstitusi negara itu harus berisi adanya pembatasan kekuasaan dan jaminan hak-hak warga negara. ${ }^{35}$

\footnotetext{
${ }^{33}$ G. Lowell Field, Government in Modern Society (London: McGraw-Hill Book Company, 1951), hal. 116

${ }^{34}$ Harun Alrasid, Naskah UUD 1945 Sesudah Empat Kali Diubah oleh MPR, Revisi Cetakan Pertama (Jakarta: Universitas Indonesia, 2003), hal. 55

${ }^{35}$ Sri Jutmini dan Winarto, Pendidikan Kewarganwgaraan (Solo: Tiga Serangkai Pustaka Mandiri, 2004), hal.148
}

Perubahan UUD kemudian dilakukan secara bertahap dan menjadi salah satu agenda Sidang Tahunan MPR dari tahun 1999 hingga perubahan keempat pada Sidang Tahunan MPR tahun 2002 bersamaan dengan kesepakatan dibentuknya Komisi Konstitusi yang bertugas melakukan pengkajian secara komperhensif tentang perubahan UUD 1945 berdasarkan Ketetapan MPR No. I/MPR/2002 tentang Pembentukan Komisi Konstitusi. $^{36}$

Perubahan pertama dilakukan dalam Sidang Tahunan MPR tahun 1999 yang meliputi Pasal 5 Ayat (1), Pasal 7, Pasal 9, Pasal 13 Ayat (2), Pasal 14, Pasal 15, Pasal 17 Ayat (2) dan (3), Pasal 20 dan Pasal 22 UUD. Kesemuanya berjumlah 9 Pasal UUD 1945. Tujuan utama perubahan ini adalah membatasi kekuasaan Presiden dan memperkuat kedudukan Dewan Perwakilan Rakyat (DPR) sebagai lembaga legislatif.

Dalam perubahan ini terjadi pergeseran kekuasaan Presiden dalam membentuk undang-undang, yang diatur dalam Pasal 5:'Presiden memegang kekuasaan membentuk

\footnotetext{
${ }^{36}$ Jimly Asshiddiqie, Menuju Negara Hukum yang Demokratis (Jakarta: Mahkamah Konstitusi, 2008), hal. 270
} 
undang-undang,"berubah menjadi Presiden berhak mengajukan rancangan undang-undang.

Kekuasaan membentuk undang-undang dialihkan kepada Dewan Perwakilan Rakyat, sebagaimana tertuang dalam Pasal 20 yang berbunyai:" Dewan Perwakilan Rakyat memegang kekuasaan membentuk undang-undang”, perubahan pasala ini memindahkan titik berat kekuasaan legislasi nasional yang semula berada di tangan Prresiden, beralih ke tangan DPR. ${ }^{37}$

\section{b. AMANDEMEN KEDUA}

Perubahan kedua dilakukan dalam sidang Tahunan MPR tahun 2000 yang meliputi Pasal 18, Pasal 18A, Pasal 18B, Pasal 19, Pasal 20 Ayat (5), Pasal 20A, Pasal 22A, Pasal 22B, BAB IXA, Pasal 28A, Pasal 28B, Pasal 28C, Pasal 28D, Pasal 28E, Pasal 28F, Pasal 28G, Pasal 28H, Pasal 28I, Pasal 28J, BAB XII, Pasal 30, Bab XV, Pasal 36A, Pasal 36B dan Pasal 36C UUD 1945. Perubahan ini terdiri dari 5 BAB dan 25 Pasal. $^{38}$ Inti dari perubahan kedua ini meliputi masalah wilayah negara dan pembagian

\footnotetext{
${ }^{37}$ Ni'matul Huda, UUD 1945 dan Gagasan Amandemen Ulang (Jakarta: Raja Grafindo Persada, 2008), hal.284

${ }^{38}$ Majda El-Mumtaj, Hak Asasi Manusia dalam Konstitusi Indonesia (Jakarta: Kencana, 2007), hal. 88.
}

pemerintahan daerah, menyempurnakan perubahan pertama dalam hal memperkuat kedudukan DPR dan ketentuan-ketentuan yang lebih merinci mengenai HAM.

Khusus mengenai pengaturan HAM, dapat dilihat pada Perubahan dan kemajuan signifikan adalah dengan dicantumkannya persoalan HAM secara tegas dalam sebuah BAB tersendiri, yakni BAB XA (Hak Asasi Manusia) dari mulai Pasal 28A sampai dengan 28J. Dapat dikatakan bahwa konseptualisasi HAM di Indonesia telah mengalami proses dialektika yang seruis dan panjang yang mengambarkan komitmen atas upaya penegakan hkum dan HAM. ${ }^{39}$

\section{c. AMANDEMEN KETIGA}

Perubahan ketiga ini terdiri dari 3 BAB dan 22 Pasal, ditetapkan pada Sidang Tahunan MPR Tahun 2001 mengubah dan atau menambah ketentuan-ketentuan Pasal 1 Ayat (2) dan (3), Pasal 3 Ayat (1), (3) dan (4), Pasal 6 Ayat (1) dan (2), Pasal 6A Ayat (1), (2), (3) dan (5), Pasal 7A, Pasal 7B Ayat (1), (2), (3), (4), (5), (6) dan (7), Pasal 7C, Pasal 8 Ayat (1) dan (2), 
Pasal 11 Ayat (2) dan (3), Pasal 17 Ayat (4), BAB VIIIA, Pasal 22C Ayat (1), (2), (3) dan (4), Pasal 22D Ayat (1), (2), (3) dan (4), BAB VIIB, Pasal 22E Ayat (1), (2), (3), (4), (5) dan (6), Pasal 23 Ayat (1), (2) dan (3), Pasal 23A, Pasal 23C, BAB VIIIA, Pasal 22E Ayat (1), (2) dan (3), Pasal 23F Ayat (1) dan (2), Pasal 23G Ayat (1) dan (2), Pasal 24 Ayat (1) dan (2), Pasal 24A Ayat (1), (2), (3), (4) dan (5), Pasal 24B Ayat (1), (2), (3) dan (4), Pasal 24C Ayat (1), (2), (3), (4), (5) dan (6) UUD 1945.

Inti perubahan yang dilakukan pada amandemen ketiga ini adalah Bentuk dan Kedaulatan Negara, Kewenangan MPR, Kepresidenan, Impeachment, Keuangan Negara, Kekuasaan Kehakiman dam ketentuanketentuan mengenai Pemilihan Umum.

\section{d. AMANDEMEN KEEMPAT}

Perubahan keempat dilakukan dalam Sidang Tahunan MPR tahun 2002. Perubahan dan atau penambahan tersebut yakni meliputi Pasal 2 Ayat (1), Pasal 6A Ayat (4), Pasal 8 Ayat (3), Pasal 11 Ayat (1), Pasal 16, Pasal 23B, Pasal 23D, Pasal 24 Ayat (3), BAB XIII, Pasal 31 Ayat (1), (2), (3),(4) dan (5), Pasal 32 Ayat (1), (2), (3) dan (4), BAB IV, Pasal 33 Ayat (4) dan (5), Pasal 34 Ayat (1), (2), (3) dan
(4), Pasal 37 Ayat (1), (2), (3), (4) dan (5), Aturan Peralihan Pasal I, II dan III, Aturan Tambahan Pasal I dan II UUD 1945. Materi perubahan pada perubahan keempat adalah ketentuan tentang kelembagaan negara dan hubungan antar negara, penghapusan Dewan Pertimbanga Agung (DPA), ketentuan mengenai pendidikan dan kebudayaan, ketentuan tentang perekonomian dan kesejahteraan sosial dan aturan peralihan serta aturan tambahan.

\section{PERUBAHAN-PERUBAHAN PENTING} PASCA AMANDEMEN

Sejarah perjalan perkembangan UUD 1945 ini memiliki beberapa tahap dalam mencapai kesempurnaannya. Konstitusi indonesia yang pertama kali ini harus kita ketahui bahwa merupakan hasil karya pemikir yang berasal dari negara jepang yaitu Dokuritsu Zyunbi Tyoosakai yamg merupakan salah satu anggota Badan Penyidik Usaha-Usaha Persiapan Kemerdekaan Indonesia pada masa penjajahan belanda dan konstitusi pertama ini diberi nama Hukum Dasar. ${ }^{40}$

Setelah Indonesia merdeka pada tahun 1945, segera saja negara yang masih baru ini mengalami berbagai hal : pergolakan politik, kerusuhan-kerusuhan,

\footnotetext{
${ }^{40}$ Endang Saifuddin, Piagam Jakarta 22 Juni 1945, Jakarta (Bandung: Salman ITB, 1981), hal. 167
} 
kesulitan ekonomi, lemahnya pemerintahan, dan agresi dari Belanda. Tekanan internal dan eksternal selama kurang lebih 4 (empat) tahun membuat pemerintah Republik Indonesia dapat dikatakan tidak berdaya untuk membenahi semua aspek kehidupan masyarakat. Sampai kemudian tercapai perundingan KMB di Den Haag, Belanda. ${ }^{41}$

UUD 1945 yang pertama di negara indonesia ini adalah merupakan produk rancangan dari panitia persiapan kemerdekaan bangsa indonesia pada tanggal 18 Agustus 1945, dan UUD 1945 ini hanya sempat berlaku empat tahun selanjutnya pemerintahan indonesia secara fundamental harus segera merubah bentuk negara, sistem pemerintahan dan UUD ini karena pemerintah tersadar bahwa UUD ini terkandung banyak perpolitikan belanda yang ingin menguasai kembali negara indonesia setelah belantera jepang menyerah kepada sekutu. ${ }^{42}$

Negara belanda memainkan politik untuk mencoba memcahkan wilayah indonesia dengan mendirikan lagi negaranegara diwilayah tanah air indonesia. Namun hal ini membuat perserikaatan bangsa-bangsa perihatin dan turun tangan lalu mendesak pemerintahan indonesia

\footnotetext{
${ }^{41}$ Purwoko, "Sistem Politik dan Pemerintah Indonesia setelah Reformasi”,Jurnal Politica, 1:1 (Universitas Dipenogoro: April, 2010), hal. 60

${ }^{42}$ Soehino, Hukum Tata Negara, Hubungan Fungsional antara Lembaga-Lembaga Negara (Yogyakarta: Liberty, 1984), hal. 6
}

agar duduk runding dengan pemerintahan belanda dan perundingan inilah yang disebut dengan Konferensi Meja Bundar yang berlangsung dari tanggal 23 agustus Sampai dengan tanggal 2 november 1949 yang diikuti oleh wakil-wakil dari Indonesia sendiri, BFO, Nederland dan komisi PBB. Dan dalam konferensi ini menghasillkan tiga buah kepsepakan pokok yaitu :

- Mendirikan Negara Republik Indonesia Serikat

- Penyerahan Kedaulatan kepada Republik Indonesia Serikatrikat

- Didirikan Uni antara Republik Indonesia Serikat dan Kerajaan Belanda

Selain dari itu terdapat juga tiga hasil persetujauan mengenai hasil pemulihan kedaulatan yang merupakan hasil dari persetyujuan pokok antara lain sebagaai berikut :

- Piagam Penyarahan Kedaulatan

- $\quad$ Status Uni

- Pesetujuan Perpindahan

Pada saat berlangsungnya perundingan tersebut terbentuklah panitia untuk membahas masalah penggantian konstitusi negara indonesia yaitu menjadi konstitusi Republik Indonesia Serikat yang terselesaikannya pada tanggal 20 Oktober 1949 dan langsung pada saat itu 
pula terjadinya penandatanganan Piagam Persetujuan Kontitusi Republik Indonesia Serikat dan konstitusi ini hanya konstitusi sementara. Pada masa ini sistem pemerintahan indonesia adalah parlementer. bentuk pemerintahan dan bentuk negaranya federasi yaitu negara yang didalamnya terdiri dari negaranegara bagian yang masing masing negara bagian memiliki kedaulatan sendiri untuk mengurus urusan dalam negerinya. ${ }^{43}$

Perubahan bentuk Negara secara otomatis juga membuat perubahan dalam konstitusinya. Mulai Pada tanggal 17 Agustus 1950 Konstitusi Indonesia berubah menjadi Undang-Undang Sementara Republik Indonesia yang selanjutnya kembali dibentuk konstitusi baru yaitu UUD Sementara tahun 1950. Pada periode UUDS 50 ini diberlakukan sistem Demokrasi Parlementer yang sering disebut Demokrasi Liberal. Pada periode ini pula kabinet selalu silih berganti, akibatnya pembangunan tidak berjalan lancar, masing-masing partai lebih memperhatikan kepentingan partai atau golongannya.

Setelah negara RI dengan UUDS 1950 dan sistem Demokrasi Liberal yang dialami rakyat Indonesia selama hampir 9 tahun, maka rakyat Indonesia sadar bahwa UUDS 1950 dengan sistem Demokrasi

\footnotetext{
${ }^{43}$ Soehino, Op., Cit.,
}

Liberal tidak cocok, karena tidak sesuai dengan jiwa Pancasila dan UUD 1945. Akhirnya Presiden menganggap bahwa keadaan ketatanegaraan Indonesia membahayakan persatuan dan kesatuan bangsa dan negara serta merintangi pembangunan semesta berencana untuk mencapai masyarakat adil dan makmur; sehingga pada tanggal 5 Juli 1959 mengumumkan dekrit mengenai pembubaran Konstituante dan berlakunya kembali UUD 1945 serta tidak berlakunya UUDS 1950.

Umur negara federal Republik Indonesia dibawah konstitusi RIS ternyata juga tidak dapat bertahan lama dibawah kekuasaan pemerintahan pada saat itu. Indonesia kembali memilih bentuk negara kesatuan utuk menajalankan roda pemerintahan di tanah air dengan membentuk konstitusi baru yaitu yang diberi nama UUDS Republik Indonesia tahun $1950 .^{44}$ Peroses perubahan Konstitusi RIS ke Konstitusi UUDS ini dilakukan dalam bentuk formal yaitu perubahan yang dilakukan berdasarkan dengan Undang-undang federal nomor 7 tahun 1950, yang didalamya terdapat penetapan mengenai perubahan Konstitusi Republik Indonesia Serikat menjadi Konstitusi Undang-Undang Dasar Sementara Republik Indonesia. Perubahan

\footnotetext{
${ }^{44}$ Moh. Kusnardi dan Hermaily Ibrahim, Op., Cit., hal. 93
} 
ini mencakup perubahan mengenai perubahan mukaddimah dan bentuk negara, yaitu dari negara federal menjadi bentuk Negara Kesatuan Republik Indonesia. $^{45}$

Karena situasi politik pada Sidang Konstituante (Lembaga yang bertugas untuk menyusun UUD 1945 yang baru) di 1959 dimana banyak saling tarik ulur kepentingan partai politik sehingga gagal menghasilkan UUD baru, maka pada tanggal 5 Juli 1959, Presiden Sukarno mengeluarkan Dekrit Presiden yang salah satu isinya memberlakukan kembali UUD 1945 sebagai undang-undang dasar, menggantikan Undang-Undang Dasar Sementara 1950 yang berlaku pada waktu itu. Pada masa ini, terdapat berbagai penyimpangan UUD 1945 yakni adalah: ${ }^{46}$

1. Presiden mengangkat Ketua dan Wakil Ketua MPR/DPR dan MA serta Wakil Ketua DPA menjadi Menteri Negara.

2. MPRS menetapkan Soekarno sebagai presiden seumur hidup.

3. Pemberontakan Partai Komunis Indonesia melalui Gerakan 30 September Partai Komunis Indonesia

Keberlakuan kembali UUD 1945 merupaka pijakan awal kejelasan status

\footnotetext{
${ }^{45}$ Muhammad Hatta, Memoir Muhammad Haat (Jakarta: Tintamas, 1982), hal. 98

${ }^{46}$ M. Jamin, Pembahasan Undang-Undang Dasar (Jakarta: Ripres Utama, 1992), hal. 134
}

negara ini, yang selanjutnya pemimpin bngsa ini pun berganti dari pinpinan Soekarno digantikan oleh Soharto, namun seiring berjalannya waktu kepemimpinan Soharto UUD 1945 dijadikan landasan untuk membuat dia sebagai pemimpin bersikan arogan, dan UUD 1945 ini dijadikan pijakan kuat tindakan-tindakan otoriter. Dan masa kepemimpinan soharto inilah yang membuat UUD 1945 sempat menjadi keramat. pada tahun 1998 yaitu menjadi akhir dari teka-teki kepemimpinan Soharto karena rakyat indonesia sudah tidak tahan dengan kondisi dan sikap kepemimpinan Soharto. Masyrakat menuntut reformasi terjadi di negara tanah air indonesia ini. Masyarakat menuntut perubahan sistem kekuasaan ke arah yang lebih demokratis. Masyarakat melakukan pemberontakan dan mulai melawan pemerintah untuk menuntut hal tersebut dan ternyata tepat pada tanggal 22 mei 1989 Soherto menyatakan dirinya mundur dari jabatan presiden. Keberhasilan masyrakat indonesia meruntuhkan zaman Orde Baru menjadi Zaman Reformasi di negara ini ternyata mampu merubah pola pandangan kekeramatan UUD 1945 yaitu akhirnya Pada sidang MPR tahun 1999 UUD 1945 berhasil diamandemenkan untuk yang pertama kalinya.

Seperti yang kita ketahui, bahwa konstitusi, terutama konstitusi tertulis 
yang dalam hal ini termasuk UUD 1945 adalah merupakan produk hukum. Produk hukum tentu tidak mungkin dapat dilepaskan dari politik dimana ketika sesuatu adalah produk hukum, disaat yang bersamaan ia juga adalah merupakan produk politik. Namun yang harus dan perlu diakui bahwa UUD 1945 yang merupakan konstitusi Indonesia adalah sumber hukum tertinggi di Indonesia serta paling fundamental sifatnya karena konstitusi merupakan hukum yang paling tinggi serta paling fundamental sifatnya karena konstitusi merupakan hukum yang paling tinggi serta paling fundamental sifatnya karena konstitusi merupakan sumber legitimasi atau landasan orientasi bentuk-bentuk hukum atau peraturan perundang-undangan lainnya ${ }^{47}$

Unsur politis dalam UUD 1945 sendiri setelah mengalami amandemen memang sangat kontras dengan saat sebelum diamandemen. Di era reformasi ini, banyak orang merayakan liberalisasi politik untuk menumbuhkan ideologi. Gerakan sosial politik dan organisasi politik yang berafiliasi sosdem dalam berbagai bentuknya mulai diskusi, seminar, ataupun penerbitan tumbuh subur. Waktu itu, ada semacam kegairahan yang tumbuh meskipun belum begitu jelas antara klaim-klaim kerakyatan

\footnotetext{
${ }^{47}$ Jimly Asshiddiqie, Pengantar Ilmu Hukum Tata Negara (Jakarta: Raja Grafindo, 2014), hal. 94
}

itu dengan sosdem, klaim-klaim populisme itu dengan sosdem,dan lain sebagianya. $^{48}$

Sistem kekuasaan tertinggi ssebelum dilakukan amandemen dinyatakan dalam penjelasan UUD 1945 adalah kedaulatan rakyat dipegang oleh suatu badan, bernama MPR (Majelis Permusyawaratan Rakyat) sebagai penjelmaan seluruh rakyat Indonesia, menetapkan UUD dan menetapkan Garis-Garis Besar Haluan Negara (GBHN), mengankat Presiden dan Wakilnya. Namun menurut UUD 1945 hasil amandemen 2002 kekuasaan tertinggi beradadi tangan rakyat dan dilaksanakan menurut UUD. ${ }^{49}$ Hal ini berarti telah terjadi suatu reformasi kekuasaan tertinggi dalam negara secara kelembagaan tinggi negara, walaupun esensinya tetap rakyat yang memiliki kekuasaan. MPR menurut UUD 1945 hasil amandemen 2002 hanya memiliki kekuasaan melakukan perubahan atas UUD, melantik Presiden dan wakilnya, memberhentikan Presiden dan atau wakilnya sesuai masa jabatan atau jikalau melakukan pelanggaran seperti yang telah ditentukn dalam UUD dan UU terkait.

Selain itu terlihat pula dalam ketentuan penyelenggara pemerintah

\footnotetext{
${ }^{48}$ Martin Manurung, Melacak Jejak Prospek Sosial Demokrasi di Indonesia, Jurnal Sosial Demokrasi, 11:4 (Jakarta: April-Juli 2011), hal. 14

${ }^{49}$ Pasal 1 Ayat (2) UUD 1945 setelah amandemen 2002
} 
negara yang tertinggi disamping MPR adalah Presiden, karena Presiden dipilih lansung oleh rakyat. ${ }^{50}$ Kekuasaan Presiden dalam UUD sebelum amandemen yang dinyatakan dalam penjelasannya:

"Dibawah Majelis Permusyawaratan Rakyat, Presiden ialah penyelenggara pemerintahan negara yang tertinggi. Dalam menjalankan pemerintahan negara, kekuasaan dan tanggungjawab adalah ditangan Presiden (Concerntration of power responsibility upon the President. ${ }^{51,}$

Selain itu, Presiden tidak lagi bertanggung jawab kepada Presiden karena kedudukan antar Presiden dan DPR telah sejajar, sehingga mereka harus saling bekerjasama dalam berbagai hal seperti membuat Undang-Undang

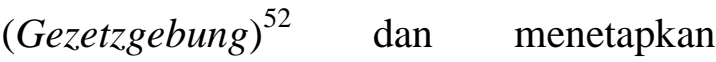
anggaran pendapatan dan belanja negara (Staatsbergrooting) $^{53}$. Dan salah satu kekuatan penting baru yang muncul dalam masa-masa amandemen UUD tepatnya pada amandemen ketiga UUD yakni adalah hadirnya kewenangan "judicial review" yakni adalah Mahkamah Konstitusi yang pada setahun semenjak berdirinya, telah mendapatkan reputasi dari kompetensi dan indepensinya.

${ }^{50}$ Pasal 6A Ayat (1) UUD 1945 setelah amandemen 2002

51 H. Kaelan dan Achmad Zubaidi, Pendidikan Kewarganegaraan untuk Perguruan Tinggi (Yogyakarta: Paradigma, 2010), hal. 90-91

52 Pasal 5 Ayat (1) UUD 1945 setelah amandemen 2002

${ }^{53}$ Pasal 23 UUD 1945 setelah amandemen 2002
Meskipun Mahkamah Konstitusi adalah di luar dari sistem perpolitikan, namun Mahkamah Konstitusi merupakan bagian penting dalam perubahan UUD.

Berikut adalah tabel perubahanperubahan amandemen yang dapat merepresentasikan keberadaan politik dalam konstitusi Indonesia yang dipergunakan untuk memoles wajah baru sistem demokrasi di indonesia :

Tabel 4.1 The People Consultative Assembly: Before and After the Amendments ${ }^{54}$

\begin{tabular}{|c|c|c|}
\hline Provisions & $\begin{array}{l}\text { Before the } \\
\text { Amandements }\end{array}$ & $\begin{array}{l}\text { After the } \\
\text { Amandements }\end{array}$ \\
\hline $\begin{array}{l}\text { People's } \\
\text { Sovereignty }\end{array}$ & $\begin{array}{l}\text { Monopolized by } \\
\text { the People } \\
\text { Consultative } \\
\text { Assembly }\end{array}$ & $\begin{array}{l}\text { The People } \\
\text { Consultative } \\
\text { Assembly does } \\
\text { not monopolize } \\
\text { the sovereignty. } \\
\text { Sovereignty shall } \\
\text { be implemented } \\
\text { in accordance } \\
\text { with the } \\
\text { Constitution }\end{array}$ \\
\hline Position & $\begin{array}{l}\text { The highest } \\
\text { state institution, } \\
\text { with unlimited } \\
\text { powers. }\end{array}$ & $\begin{array}{l}\text { The People } \\
\text { Consultative } \\
\text { Assembly is one } \\
\text { of several } \\
\text { institutions with } \\
\text { limited powers. }\end{array}$ \\
\hline $\begin{array}{l}\text { Presidential } \\
\text { Election }\end{array}$ & $\begin{array}{l}\text { Elected by the } \\
\text { People } \\
\text { Consultative } \\
\text { Assembly }\end{array}$ & $\begin{array}{l}\text { The People } \\
\text { Consultative } \\
\text { Assembly } \\
\text { inaugurates the } \\
\text { President and } \\
\text { Vice President, } \\
\text { who are directly } \\
\text { elected by the }\end{array}$ \\
\hline
\end{tabular}

\footnotetext{
${ }^{54}$ Clauspeter Hill, Constitutionalism in Southeast Asia (Singapore: Konrad Adenauer Stiftung, 2008), hal. 109
} 


\begin{tabular}{|c|c|c|}
\hline & & people \\
\hline $\begin{array}{l}\text { The Broad } \\
\text { Guidelines } \\
\text { of State } \\
\text { Policy } \\
\text { (GBHN) }\end{array}$ & $\begin{array}{l}\text { Prepared by the } \\
\text { People } \\
\text { Consultative } \\
\text { Assembly, the } \\
\text { President } \\
\text { should } \\
\text { implement and } \\
\text { account for } \\
\text { implementation } \\
\text { to the People } \\
\text { Consultative } \\
\text { Assembly }\end{array}$ & $\begin{array}{l}\text { The People } \\
\text { Consultative } \\
\text { Assembly does } \\
\text { not have this } \\
\text { authority. }\end{array}$ \\
\hline $\begin{array}{l}\text { Constitution } \\
\text { al } \\
\text { amendment }\end{array}$ & $\begin{array}{l}\text { Amended and } \\
\text { determined by } \\
\text { the People } \\
\text { Consultative } \\
\text { Assembly }\end{array}$ & $\begin{array}{l}\text { The People } \\
\text { Consultative } \\
\text { Assembly still } \\
\text { has these } \\
\text { authorities. } \\
\text { (although the } \\
\text { amendment } \\
\text { procedures have } \\
\text { been changed). }\end{array}$ \\
\hline $\begin{array}{l}\text { Presidential } \\
\text { Impeach } \\
\text { ment }\end{array}$ & $\begin{array}{l}\text { Removed by the } \\
\text { People } \\
\text { Consultative } \\
\text { Assembly. The } \\
\text { procedure was } \\
\text { not explicitly } \\
\text { stipulated in the } \\
\text { Constitution. }\end{array}$ & $\begin{array}{l}\text { The People } \\
\text { Consultative } \\
\text { Assembly has } \\
\text { the power to } \\
\text { remove the } \\
\text { President. This } \\
\text { power } \\
\text { explicitly } \\
\text { stipulated in } \\
\text { detail in the } \\
\text { Constitution }\end{array}$ \\
\hline $\begin{array}{l}\text { Vacant } \\
\text { Presidency }\end{array}$ & $\begin{array}{l}\text { The } \\
\text { Constitution } \\
\text { was silent on } \\
\text { this. }\end{array}$ & $\begin{array}{l}\text { The People } \\
\text { Consultative } \\
\text { Assembly has } \\
\text { the power to } \\
\text { elect the } \\
\text { President and/or } \\
\text { Vice President, } \\
\text { in the case that } \\
\text { one or both of } \\
\text { the positions } \\
\text { become vacant. }\end{array}$ \\
\hline
\end{tabular}

Tabel 4.2 DPR, before and after amandement $^{55}$

\begin{tabular}{|l|l|l|}
\hline NO & Before & After \\
\hline 1 & $\begin{array}{l}\text { The Constitution did not } \\
\text { clearly stipulate that the DPR } \\
\text { had legislative, budgetary }\end{array}$ & $\begin{array}{l}\text { Clearly } \\
\text { stipulated. }\end{array}$ \\
\hline
\end{tabular}

\footnotetext{
${ }^{55}$ Ibid., hal. 110-111
}

\begin{tabular}{|c|c|c|}
\hline & and supervisory functions. & \\
\hline 2 & $\begin{array}{l}\text { The Constitution did not } \\
\text { stipulate that the DPR had } \\
\text { the right of interpellation, the } \\
\text { right to carry out inquiries } \\
\text { and the right to express its } \\
\text { opinion. }\end{array}$ & Stipulated. \\
\hline 3 & $\begin{array}{l}\text { The Constitution did not } \\
\text { stipulate that each of the } \\
\text { members of the DPR had the } \\
\text { right to submit questions, to } \\
\text { convey suggestions and } \\
\text { opinions, and a right of } \\
\text { immunity }\end{array}$ & Stipulated \\
\hline 4 & $\begin{array}{l}\text { The Constitution stipulated } \\
\text { that the DPR's agreement } \\
\text { was required to declare war, } \\
\text { make peace and conclude } \\
\text { treaties; and to promulgate a } \\
\text { government regulation in } \\
\text { lieu of law to become a } \\
\text { statute. }\end{array}$ & $\begin{array}{l}\text { Has similar } \\
\text { powers. }\end{array}$ \\
\hline 5 & $\begin{array}{l}\text { The Constitution did not } \\
\text { stipulate that the DPR's } \\
\text { agreement was required: to } \\
\text { make an international } \\
\text { agreement; to approve and } \\
\text { confirm the candidate judges } \\
\text { of the Supreme Court; to } \\
\text { appoint and remove the } \\
\text { members of the Judicial } \\
\text { Commission. }\end{array}$ & Stipulated. \\
\hline 6 & $\begin{array}{l}\text { The Constitution did not } \\
\text { stipulate that the DPR } \\
\text { selected } \\
\text { the members of the state } \\
\text { Audit Board, and three } \\
\text { judges of the Constitutional } \\
\text { Court. }\end{array}$ & Stipulated. \\
\hline 7 & $\begin{array}{l}\text { The Constitution did not } \\
\text { stipulate that the DPR } \\
\text { selected } \\
\text { the members of the state } \\
\text { Audit Board, and three } \\
\text { judges of the Constitutional } \\
\text { Court. }\end{array}$ & Stipulated. \\
\hline 8 & $\begin{array}{l}\text { The Constitution stipulated } \\
\text { that the DPR received the } \\
\text { report from the state Audit } \\
\text { Board. }\end{array}$ & $\begin{array}{l}\text { Has similar } \\
\text { powers. }\end{array}$ \\
\hline 9 & $\begin{array}{l}\text { The Constitution did not } \\
\text { clearly stipulate the DPR's } \\
\text { role } \\
\text { in an impeachment process. }\end{array}$ & $\begin{array}{l}\text { Clearly } \\
\text { stipulated. }\end{array}$ \\
\hline 10 & $\begin{array}{l}\text { The elucidation of the } \\
\text { Constitution stipulated that } \\
\text { the } \\
\text { President could not dissolve }\end{array}$ & $\begin{array}{l}\text { Clearly } \\
\text { stipulated in } \\
\text { the body of } \\
\text { the }\end{array}$ \\
\hline
\end{tabular}




\begin{tabular}{|l|l|l|}
\hline & the DPR . & Constitution. \\
\hline
\end{tabular}

Dari Tabel 4.2, Implikasi terhadap perubahan struktur ketatanegaraan Indonesia pasca Perubahan UUD 1945 dari yang Pertama sampai dengan yang Keempat terutama yang berkaitan dengan kekuasaan dalam negara, telah mengakibatkan terjadinya pergeseran kekuasaan dari lembaga eksekutif kepada lembaga legislatif (executive heavy ke arah legislatif heavy). Hal ini dapat diamati dari adanya reduksi kekuasaan dalam ketentuan Pasal-pasal mengenai Presiden, dan sebaliknya terjadi penguatan kekuasaan dalam ketentuan Pasalpasal mengenai DPR yang menyebabkan DPR menjadi lembaga yang supreme. ${ }^{56} \mathrm{Hal}$ ini lebih lanjut juga diungkapkan oleh Prof. Jimly dengan menyatakan bahwa bahkan DPR ikut terlibat dalam penerimaan duta besar sebagai contoh bagaimana kekuatan DPR pasca diamandemennya UUD.

Dengan perubahan pasal-pasal tersebut, hasil perubahan MPR telah berhasil meletakkan sendi-sendi checks and balances, termasuk membatasi kekuasaan eksekutif, MPR telah berhasil mengubah dengan tegas tentang darimana kedaulatan diperoleh (locus of souvereignty). MPR yang terdiri anggota-

\footnotetext{
${ }^{56}$ Jimly Asshidiqie, Konsolidasi Naskah UUD 1945 Setelah Perubahan Keempat (Jakarta: PSHTN

Fakultas Hukum Universitas Indonesia, 2000), hal. 7.
}

anggota DPR dan anggota-anggota DPD merupakan realisasi demokrasi perwakilan. Sebagai lembaga negara, MPR hanya eksis ketika DPR dan DPD berada dalam sidang gabungan (joint session). ${ }^{57}$

Tabel 4.3 The Presidential System:

Before and After the Amendments ${ }^{58}$

\begin{tabular}{|c|c|c|}
\hline Provisions & Before & After \\
\hline $\begin{array}{c}\text { One Person or } \\
\text { Collegiate }\end{array}$ & One Person. & One person. \\
\hline Status & $\begin{array}{c}\text { Chief of } \\
\text { Executive. }\end{array}$ & The same. \\
\hline Election Process & $\begin{array}{l}\text { Indirect, by the } \\
\text { People } \\
\text { Consultative } \\
\text { Assembly }\end{array}$ & $\begin{array}{l}\text { Directly elected } \\
\text { by the people }\end{array}$ \\
\hline \multirow[t]{2}{*}{ Tenure } & $\begin{array}{l}\text { Unlimited, } \\
\text { could be re- } \\
\text { elected every } 5 \\
\text { years. }\end{array}$ & $\begin{array}{l}\text { Limited for a } \\
\text { maximum two } \\
\text { terms of } 5 \\
\text { years. }\end{array}$ \\
\hline & $\begin{array}{l}\text { Not fixed, } \\
\text { easily } \\
\text { removed. }\end{array}$ & $\begin{array}{c}\text { Fixed, not } \\
\text { easily removed }\end{array}$ \\
\hline $\begin{array}{l}\text { Legislative } \\
\text { Powers }\end{array}$ & $\begin{array}{c}\text { More } \\
\text { dominant than } \\
\text { the DPR. }\end{array}$ & $\begin{array}{c}\text { Shares powers } \\
\text { with the DPR } \\
\text { and DPD. }\end{array}$ \\
\hline $\begin{array}{l}\text { Appointment and } \\
\text { removal } \\
\text { Powers of high } \\
\text { ranking state } \\
\text { officials. }\end{array}$ & $\begin{array}{l}\text { Not clearly } \\
\text { stipulated. In } \\
\text { practice, these } \\
\text { powers are, } \\
\text { therefore, } \\
\text { unlimited. }\end{array}$ & Limited. \\
\hline \multicolumn{3}{|l|}{$\begin{array}{l}\text { Impeachment } \\
\text { Procedure: }\end{array}$} \\
\hline $\begin{array}{l}\text { 1. Legal } \\
\text { Basis }\end{array}$ & $\begin{array}{c}\text { Generally } \\
\text { mentioned in } \\
\text { the elucidation } \\
\text { of the }\end{array}$ & $\begin{array}{l}\text { Stipulated in } \\
\text { the Constitution }\end{array}$ \\
\hline
\end{tabular}

\footnotetext{
${ }^{57}$ Ni'matul Huda, “Gagasan Amandemen (Ulang) UUD 1945 (Usulan untuk Penguatan DPD dan Kekuasaan Kehakiman)", Jurnal Hukum, 3:15 (Yogyakarta: Juli 2008), hal. 374

${ }^{58}$ Clauspeter Hill., Loc., Cit., hal. 113
} 


\begin{tabular}{|c|c|c|}
\hline & $\begin{array}{l}\text { Constitution, } \\
\text { and was } \\
\text { mostly } \\
\text { stipulated in a } \\
\text { People } \\
\text { Consultative } \\
\text { Assembly } \\
\text { Decree. }\end{array}$ & \\
\hline 2. Reasons & $\begin{array}{l}\text { More political } \\
\text { than legal: if } \\
\text { the President } \\
\text { 'truly } \\
\text { breached' state } \\
\text { policy and the } \\
\text { Constitution. }\end{array}$ & $\begin{array}{l}\text { More criminal. } \\
\text { That is if the } \\
\text { President is } \\
\text { convicted of } \\
\text { 'treason, } \\
\text { corruption, } \\
\text { other high } \\
\text { crimes or } \\
\text { misdemeanors, } \\
\text { or proven to no } \\
\text { longer fulfill } \\
\text { the } \\
\text { requirements of } \\
\text { the office of } \\
\text { President'. }\end{array}$ \\
\hline $\begin{array}{l}\text { 3. Judicial } \\
\text { Branch }\end{array}$ & $\begin{array}{l}\text { Not involved } \\
\text { in the process. }\end{array}$ & $\begin{array}{l}\text { Involved. The } \\
\text { Constitutional } \\
\text { Court shall } \\
\text { investigate, try } \\
\text { and decide on } \\
\text { recommendatio } \\
\text { n by the DPR } \\
\text { that the } \\
\text { President } \\
\text { should be } \\
\text { impeached. }\end{array}$ \\
\hline
\end{tabular}

\section{Penutup}

Undang-Undang Dasar Negara

Republik Indonesia Tahun 1945 (UUD 1945)

dalam Proses sejarah, telah melalui 4 tahapan perubahan yakni adalah: Undang-Undang Dasar 1945 (Periode 18 Agustus 1945 - 27 Desember 1949); Undang-Undang Dasar RIS (Periode 27 Desember 1949 - 17 Agustus 1950); Undang-Undang Dasar Sementara 1950 (Periode 17 Agustus 1950 5 Juli 1959); Kembali ke UUD 1945 (Periode 5 Juli 1959 - sekarang)

Sementara itu, dalam proses perubahan konstitusi pasca kembalinya ke UUD 1945,
Indonesia telah melakukan setidaknya empat kali amandemen, yakni : Amandemen Pertama (1999); Amandemen kedua (2000); Amandemen ketiga (2001); Amandemen keempat (2002).

Adapun perubahan mendasar dari Undang-Undang Dasar yakni jelas sekali terlihat dalam berbagai perjalanan perubahan konstitusi di Indonesia. Jika melihat pada proses perubahan Konstitusi dari sejarahnya, beberapa kali kekuatan politik dipergunakan untuk mentafsirkan konstitusi. Seperti yang terjadi saat Soekarno mengangkat dirinya sebagai presiden seumur hidup atau digunakannya Undang-Undang Dasar sebagai alat untuk mendukung pemerintahan otoriter Soeharto. Dalam proses perubahannya melalui amandemen, politik ikut mewarnai berbagai situasi kebatinan konstitusi. Misalnya adalah perubahan executive heavy ke legislative heavy, kemudian pengaturan yang ketat mengenai masa jabatan presiden dan bagaimana ia dapat dipilih kembali dalam satu periode berikutnya, kemudian bagaimana cara mengimpech presiden.

Penulis sangat menyadari bahwa politik tidak mungkin dapat dilepaskan dari sistem hukum. Begitu juga dengan hukum, tidak mungkin dapat dilepaskan dari sistem perpolitikan. Keduanya saling bersinergi satu sama lainnya sehingga menciptakan suatu sitstem pemerintahan yang diharapkan menajadi pemerintahan yang baik dan 
mendatangkan manfaat bagi seluruh rakyat. Akan tetapi penulis berpandangan kerap kali hukum dijadikan alat berpolitik untuk memuluskan keinginan segelintir orang.

Penulis sangat berharap, sebagai penggerak roda kehidupan bernegara, masyarakat dapat memahami pola-pola politik dan hukum yang ada sehingga mampu mengawal kehidupan bernegara khusunya di Indonesia. Khususnya konstitusi. Seperti yang kita ketahui bahwa konstitusi adalah landasan aturan bagi Indonesia. Semua aturan yang sifatnya lebih konkrit haruslah berlandaskan oleh konstitusi. Masyrakat harus pandai melihat aura-aura politis di dalamnya dan mampu bersikap kritis bila hal tersebut dianggap merugikan bangsa dan negara.

Selain itu penulis juga berharap agar mereka yang berwenang dalam melakukan perubahan kosntitusi (kelak bila hendak melakukan perubahan lagi) dapat memperhatikan tindakan-tindakan politis yang diambil. Jangan mementingkan segelintir orang apalagi pribadi. Diharapkan keberadaan politik dalam konstitusi dapat menunjang kemajuan masyarakat secara keseluruhan.

\section{DAFTAR PUSTAKA}

Alrasid, Harun. (2003). Naskah UUD 1945 Sesudah Empat Kali Diubah oleh MPR, Revisi Cetakan Pertama. Jakarta: Universitas Indonesia
Amanwinata, Rukmana. (2007). Pengaturan dan Batas Implementasi Kemerdekaan Berserikat dan Berkumpul Dalam pasal 28 UUD 1945 dalam Ellydar Chaidir, Hukum dan Teori Konstitusi. Yogyakarta: Total Media

Arinanto, Satya. (2000). Constitutional Law and Democratization in indonesia . Jakarta: Publishing House Faculty of Law University of Indonesia

Asshidiqie, Jimly. (2000). Konsolidasi Naskah UUD 1945 Setelah Perubahan Keempat. Jakarta: PSHTN Fakultas Hukum Universitas Indonesia . (2008). Menuju Negara Hukum yang Demokratis. Jakarta: Mahkamah Konstitusi (2014). Konstitusi dan Konstitusionalisme Indonesia. Jakarta: Sinar Grafika (2014). Pengantar Ilmu Hukum Tata Negara. Jakarta: Raja Grafindo

Azhary. (1995). Negara Hukum Indonesia Analisis Yuridis Normatif Tentang Unsur-Unsurnya. Jakarta: Universitas Indonesia Press

Bahar, Saefroedin, et. al. 1992. Risalah Sidang BPUPKI-PPKI. Jakarta: Sekretariat Negara

Republik Indonesia, 1992

Bakry, Noor MS. (1994). Pancasila Yuridis Kenaegaraan . Yogyakarta: Liberty

Barendt, Eric. (1998). Introduction to Constitutional Law. Inggris: Oxford University Press 
Budiardjo, Miriam. (2006). Dasar-Dasal Ilmu Politik . Jakarta: Garmedia

Crouch, Harold. (2004). Indonesia Democratization and Threat of Disintegration dalam Politik Hukum 2 oleh Prof Satya Arinanto. Jakarta: Program Pasca Sarjana, Fakultas Hukum, Universitas Indonesia

Effendi, Bachtiar. (2000). Repolitisasi Islam: Pernahkah Islam Berhenti Berpolitik?. Jakarta: Mizan

El-Mumtaj, Majda. (2007). Hak Asasi Manusia dalam Konstitusi Indonesia Jakarta: Kencana.

Fadjar, Mukthie. (2003). Reformasi Konstitusi dalam Masa Transisi Paradigmatik . Malang: In-Trans

Farida, Maria. Ilmu Perundang-Undangan: Jenis, Fungsi dan Materi Muatan. Yogyakarta: Kanisius

Field, G. Lowell. (1951). Government in Modern Society . London: McGrawHill Book Company

Hatta, Muhammad. (1982). Memoir Muhammad Haat. Jakarta: Tintamas

Hill, Clauspeter. (2008). Constitutionalism in Southeast Asia. Singapore: Konrad Adenauer Stiftung

Huda, Ni'matul. (2008). UUD 1945 dan Gagasan Amandemen Ulang. Jakarta: Raja Grafindo Persada

Jutmini, Sri dan Winarto. (2004). Pendidikan Kewarganwgaraan. Solo: Tiga Serangkai Pustaka Mandiri

Jamin. M. (1992). Pembahasan UndangUndang Dasar. Jakarta: Ripres Utama

Kaelan, H. dan Achmad Zubaidi. (2010). Pendidikan Kewarganegaraan untuk Perguruan Tinggi. Yogyakarta: Paradigma
Kelsen, Hans. (2004). General Theory of Law dalam Politik Hukum 2 oleh Prof. Satya

Arinanto. Jakarta: Program Pasca Sarjana Fakultas Hukum Universitas Indonesia

Kusuma, RM. A.B. (2011). Sistem Pemerintahan "Pendiri Negara" Versus Sistem Presidensiel "Orde Reformasi”. Jakarta: Fakultas Hukum Universitas Indonesia

Kusnardi, Moh. dan Harmaily Ibrahim,. (1983). Pengantar Hukum Tata Negara indonesia . Jakarta: Fakultas Hukum universitas Indonesia

Manan, Bagir. (1994). Pertumbuhan dan Perkembangan Konstitusi Suatu Negara. Bandung: Mandar Maju

Marzuki, Peter Mahmud. (2010). Penelitian Hukum . Jakarta: Kencana Prenada Media

Nasution, Adnan Buyung. (1992). The Aspiration for Constitutional Government in Indonesia: A Socio Legal Study of the Indonesian Konstituante, 1956-1959. Jakarta: Pustaka Sinar Harapan

Prodjokoro, Wirjono. (1977). Azas-azas Hukum Tata Negara di Indonesia. Jakarta: Dian Rakyat

Saifuddin, Endang. (1981). Piagam Jakarta 22 Juni 1945, Jakarta. Bandung: Salman ITB

Soehino. (1984). Hukum Tata Negara, Hubungan Fungsional antara Lembaga-Lembaga Negara. Yogyakarta: Liberty

Soemantri, Sri. (1981). Pengantar Perbandingan Antar Hukum Tata Negara. Jakarta: Rajawali 
Soematri, Sri. (2006). Prosedur dan Sistem Perubahan Konstitusi. Bandung Alumni

Thaib, Dahlan, et. al. (2004). Teori dan Hukum Konstitusi . Jakarta: Rajawali Press

Yamin, Muhammad. 1971. Naskah Persiapan Undang-Undang Dasar 1945. Jakarta: Siguntang

\section{SUMBER LAIN:}

Kus Edy Sartono. "Kajian Konstitusi Indonesia dari Awal Kemerdekaan Hingga Era Reformasi". Jurnal Humanika. Volume, No. 1. Yogyakarta: Maret 2009

Martin Manurung. Melacak Jejak Prospek Sosial Demokrasi di Indonesia. Jurnal Sosial Demokrasi. Volume 11, No. 4. Jakarta: April-Juli 2011
Miftakhul Huda. "Pengujian UU dan Perubahan Konstitusi: Mengenal Lebih Dekat Gagasan Sri Soemantri”. Jurnal Konstitusi. Volume 6, No.4. Jakarta: November 2009

Ni'matul Huda. “Gagasan Amandemen (Ulang) UUD 1945 (Usulan untuk Penguatan DPD dan Kekuasaan Kehakiman)". Jurnal Hukum. Volume 3, No. 15. Yogyakarta: Juli 22008

Purwoko. "Sistem Politik dan Pemerintah Indonesia setelah Reformasi". Jurnal Politica. Volume. 1, No. 1. Universitas Dipenogoro: April, 2010

Satya Arinanto. "Politik Pembangunan Hukum Nasional dalam Era Pasca Reformasi”. Makalah diberikan pada perkuliahan Politik Hukum Program Pasca Sarjana 2016

Website Mahkamah Konstitusi (https://mkri.id/index.php?page=web.B erita\&id=11776) 